\title{
A BIBLIOMETRIC ANALYSIS OF THE JoURnal OF ECONOMIC AND FinanCIAL SCIENCES (2007-2016)
}

\author{
Nicolaas Strydom* \\ University of Johannesburg
}

Received: July 2016

\author{
Gideon Els" \\ University of Johannesburg
}

Accepted: October 2016

\begin{abstract}
The Journal of Economic and Financial Sciences (JEF) reaches its tenth year of publishing in 2016. This paper explores the manuscript characteristics, authorship dynamics and main research trends of the journal's first decade by analysing 245 published academic papers that appeared in the journal between 2007 and 2016. Using the principles of bibliometrics, the body of literature is analysed, with a number of trends emerging. The analysis explores, inter alia, the geographic distribution of contributing institutions, the degree of collaboration, and the main topics that were focused on in the journal's first decade. The analysis shows that the majority of papers were written by more than one author, with contributing institutions spread out across South Africa. Furthermore, the analysis shows that the journal focussed mainly on matters of Economics (more specifically development economics, economic geography, economic growth and economic impact of certain events), Taxation (more specifically income tax matters, research on various Tax Acts, and tax compliance) and Finance (more specifically, research on financial crises, financial development, financial distress, financial performance, financial markets, and financial reporting/statements), while also making contributions to the fields of education, economic sociology, tourism studies and others.
\end{abstract}

\section{Keywords}

Bibliometrics; content analysis; scientific communication; manuscript characteristics; authorship; research topics

*Mr NT Strydom is a doctoral student in the Department of Finance and Investment Management, University of Johannesburg, South Africa [nicost@uj.ac.za].

\#Prof $\mathbf{G}$ हls is an associate professor in the Department of Finance and Investment Management, University of Johannesburg, South Africa. 


\section{INTRODUCTION}

In the development of any academic field, there are natural and regular instances of introspection whereby the fundamental nature of the field, its progress and development and its future prospects are explored, evaluated and, sometimes, refocused. The same can be argued for the academic journal as a vehicle of scientific communication. Academic journals have evolved from news bulletins for likeminded intellectuals to vehicles for disseminating the latest research within a certain field or discipline. Such introspection seems appropriate at the end of the Journal of Economic and Financial Sciences' (JEF) first decade in existence.

The JEF is an academic research journal based in the Faculty of Economic and Financial Sciences (FEFS) at the University of Johannesburg (UJ), South Africa. The journal publishes "theoretical, empirical and applied research in the field of Economic and Financial Sciences. Manuscripts published in the JEF fall mostly in the areas of auditing, corporate finance, corporate governance, economics, econometrics, financial accounting, financial management, financial planning, investment management, management accounting and taxation in the emerging market field" (Journal of Economic and Financial Sciences, 2015). The journal offers a platform for researchers from a variety of academic backgrounds to publish their research and form part of an interdisciplinary academic conversation. This approach is reflected in an excerpt from the first editorial of the Journal: "[T] he journal should serve as a vehicle for the dissemination of generalist research and knowledge, not just within a subject, but more broadly within a field of expertise" ( $\varepsilon l s, 2007: 5)$. This mimics the structures of many tertiary courses in economic and financial sciences, where knowledge is created and shared on a variety of topics, rather than only within a single, highly specialised sub-discipline.

This paper aims to explore the history and development of the JEF to serve as a case study of journal development, in order to better understand the trajectory of the journal's development over its first decade. To this end, a variety of characteristics of the 245 academic articles published in the journal between 2007 and 2016 are examined. The methods of analysis are detailed in the methodology section.

To understand the development and changing characteristics of the journal as a body of research, this study takes a bibliometric approach. Bibliometrics can be defined as "the quantitative study of physical published units, or of bibliographic units, or of the surrogates for either" (Broadus, 1987:376). This approach has been adopted in a number of published studies on the evolution of a journal (see for example Dabirian, Diba \& Treen, 2016; Paschen, Wilson, Nehajowich \& Prpic, 2016; Merigó, Mas-Tur, Roig-Tierno \& Ribeiro-Soriano, 2015; Dobson, 2009; and Muncy \& Eastman, 1998), and it offers in-depth insight into the characteristics of the journal as a body of knowledge. An analysis of the research trends within the journal also offers regular users of the journal the opportunity to further (by publishing in the journal) the academic debates that are identified here.

The paper offers regular readers of the journal an opportunity to reflect on the developments of the journal over the last decade, allowing them "to identify the evolution of a field as well as the contributions made to the field or associated fields" (Polonsky \& Ringer, 2012). Retrospection at the dawn of the journal's second decade also offers an opportunity to re-evaluate the strategic direction and scope of the journal, in order to expand its capacity to serve the academic community that uses the journal as a vehicle for scientific communication and the dissemination of new information. 
The paper is structured in four major sections. Firstly, the methodology of the bibliometric analysis is discussed, followed by the results, the discussion of the results, a conclusion and suggestions for further research.

\section{PREPARATIONS FOR THE LAUNCH OF THE JOURNAL}

The UJ was formally constituted on 1 January 2005 as the result of the merger between the former Rand Afrikaans University (RAU) and the former Technikon Witwatersrand (TWR) and the incorporation of certain campuses of Vista University. As a result of the merger the Faculty of Economic and Financial Sciences was created (as one of nine faculties) consisting of academic departments for Accounting, Commercial Accounting, Economics and Econometrics and Finance and Investment Management.

One of the strategic goals of the newly formed institution was to focus on the increase of accredited research output with a wide national and international footprint. In order to augment this institutional vision, the FEFS started the process of developing and creating an academic journal in 2005. The formation and creation of the journal was preceded by many hours of 'research' and an understanding of the academic landscape in which the journal will operate.

Strategically it was also decided that the journal should provide an option to publish in the wider realm of finance and investment management. Other issues that were also discussed and thoroughly investigated were the options of hard copy versus online publication; the look and feel of the journal; and the determination of an acceptable Editorial Policy for the journal. The first edition of the journal was thus published in April 2007.

\section{METHODOLOGY}

To better understand the publication dynamics of the Journal of Economic and Financial Sciences' first decade, this study takes a bibliometric approach. Bibliometrics can be defined as "the quantitative study of physical published units, or of bibliographic units, or of the surrogates for either" (Broadus, 1987:376). Bibliometric studies are considered a "paramount instrument in the study and assessment of research activities... and scholars" (Dabirian et al., 2016:1), and offers insight into scientific specialisation of individuals and countries (Okubo, 1997). The field of bibliometrics can be traced to a number of origins: Firstly, publication counts in the legal field, dating back to the early $19^{\text {th }}$ century (Shapiro, 1990). Secondly, the 1917 study of publication counts per country by F.J. Cole and N.B. Eales is often cited as one of the pioneering bibliometric works (Shapiro, 1990; Hertzel, 1987). Finally, the field became more formalised when Alan Pritchard coined the term Bibliometrics in his 1969 paper titled 'Statistical Bibliography or Bibliometrics?'(Pritchard, 1969; White \& McCain, 1989; Hood \& Wilson, 2001).

The analysis is focussed on the published academic papers as units of certified knowledge (Ramos-Rodríguez \& Ruíz-Navarro, 2004), and therefore ignores the editorials, commentaries and other miscellaneous items as non-academic units of publication (Paschen et al., 2016). The analysis of published academic articles offers comprehensive insight into the trends, characteristics and dynamics of the Journal's first decade.

Studies of scholarly literature may take on a variety of approaches, as highlighted by Pasadeos, Phelps, and Kim (1998): 
1. Comprehensive review: to synthesize the general conclusions from a number of papers on the same topic;

2. Methodological investigation: to explore the methodological approaches of a body of literature on a specific topic or discipline;

3. Studies of publishing productivity: to explore the level of contribution to a body of literature by authors and institutions;

4. Studies of specific journals: to explore the in-depth characteristics of a body of literature in a single journal (also see Merigó et al., 2015);

5. Citation analysis: to explore the impact of a collection of scholarly publications.

This paper takes a hybrid approach, by studying the dynamics of publishing productivity (approach 3) of a specific journal (approach 4). With this hybrid approach in mind, the study is guided by the following research questions:

1. What were the manuscript characteristics of the JEF during its first decade?

2. What are the authorship dynamics of the JEF during its first decade?

3. What are the main research trends and topics that the JEF focused on in its first decade?

The data requirements and variables of such a bibliometric analysis are determined and described in the next section, followed by the results of the bibliometric analysis.

\section{DATA AND VARIABLES}

Data were gathered from the entire collection of academic articles published in Volume 1 , Issue 1 (April 2007) to Volume 9, Issue 2 (July 2016), by analysing a variety of characteristics of each paper, including manuscript characteristics, article activity, authorship, and research topics (as described in TABLE 2). During this period, a total of 245 academic articles appeared in the journal. The number of papers per year steadily increased, as the journal was published biannually between 2007 and 2012, and tri-annually from 2012 onwards. For each article, a number of attributes were recorded in a spreadsheet with a pre-determined coding scheme (Paschen et al., 2016). The analysis in the spreadsheet is also augmented by a more in-depth research topic and keyword analysis using $\mathrm{NVivo}^{\circledR}{ }^{\circledR}$ qualitative data analysis software. This software also enabled the researchers to visualise the relationships between keywords and concepts found in the journal. This is presented in the results section.

In terms of the variable selection, this paper adopts a hybrid approach based on a number of similar studies. As many journals have achieved a coming-of-age during the last number of decades, there are many instances where a bibliometric analysis is undertaken to chart the trajectory of development of an individual journal. A number of journal articles with a variety of approaches to journal bibliometric analysis is analysed and summarized in TABLE 1 . 


\section{TABLE 1: Common variables of a bibliometric analysis}

\begin{tabular}{|c|c|c|}
\hline Group & Reference & Variables \\
\hline $\begin{array}{l}\text { Publication } \\
\text { times }\end{array}$ & $\begin{array}{l}\text { Armstrong and Wilkenson } \\
(2007)\end{array}$ & $\begin{array}{l}\text { Average time taken to acknowledge receipt } \\
\text { of article; Average time to reach first } \\
\text { decision cycle; Average time taken for } \\
\text { second complete review cycle; Average time } \\
\text { to accept an article; Average time from } \\
\text { acceptance to online publication; Average } \\
\text { time from acceptance to print publication }\end{array}$ \\
\hline $\begin{array}{l}\text { Acceptance } \\
\text { rates }\end{array}$ & $\begin{array}{l}\text { Armstrong and Wilkenson } \\
(2007)\end{array}$ & $\begin{array}{l}\text { Percentage of articles returned for further } \\
\text { work; Percentage of articles rejected } \\
\text { without sending to Associate Editors; } \\
\text { Percentage of articles entering review } \\
\text { process; Percentage of articles currently in } \\
\text { review cycles; Percentage of articles } \\
\text { rejected after review process; Article } \\
\text { acceptance rate; Articles withdrawal rate }\end{array}$ \\
\hline
\end{tabular}

$\begin{array}{lll}\begin{array}{l}\text { Volume of } \\ \text { research }\end{array} & \begin{array}{l}\text { Dabirian et al. (2016); Merigó } \\ \text { et al. (2015); Quevedo-Blasco } \\ \text { and Ariza (2013); Van Fleet, }\end{array} & \text { Number of articles per year; } \\ & \begin{array}{l}\text { Ray, Bedeian, Downey, Hunt, } \\ \text { Griffin, Dalton, Vecchio, } \\ \text { Kacmar, and Feldman (2006) }\end{array} & \\ \text { Manuscript } & \begin{array}{l}\text { Dabirian et al. (2016); Paschen } \\ \text { et al. (2016); Quevedo-Blasco } \\ \text { and Ariza (2013); Simon, }\end{array} & \begin{array}{l}\text { Average page length per article; Average } \\ \text { number of tables and figures per article; } \\ \text { Coronado, Wurtzel, Riddle and } \\ \text { George (2014) }\end{array}\end{array}$

\begin{tabular}{|c|c|c|}
\hline Article activity & $\begin{array}{l}\text { Armstrong and Wilkenson } \\
\text { (2007); Dabirian et al. (2016); } \\
\text { Merigó et al. (2015); Paschen et } \\
\text { al. (2016); Polonsky and Ringer } \\
\text { (2012); Puevedo-Blasco and } \\
\text { Ariza (2013); Simon et al. } \\
\text { (2014); Van Fleet et al. (2006) }\end{array}$ & $\begin{array}{l}\text { Most downloaded articles; Most cited } \\
\text { articles; Average citations per article }\end{array}$ \\
\hline Authorship & $\begin{array}{l}\text { Dabirian et al. (2016); Dobson } \\
\text { (2009); Lee and Taylor (2013); } \\
\text { Merigó et al. (2015); Paschen et } \\
\text { al. (2016); Polonsky and Ringer } \\
\text { (2012); Quevedo-Blasco and } \\
\text { Ariza (2013); Van Fleet et al. } \\
\text { (2006) }\end{array}$ & $\begin{array}{l}\text { Degree of collaboration; Authors per article; } \\
\text { Top contributing institutions (units } \\
\text { contributed, papers contributed); Top } \\
\text { contributing authors (units contributed, } \\
\text { papers contributed); Top author countries; } \\
\text { Author affiliation type (professional, } \\
\text { education, government); Author gender; } \\
\text { Educational level of authors (Masters, PhD, } \\
\text { Experienced researcher) }\end{array}$ \\
\hline
\end{tabular}

Research topics Dabirian et al. (2016); Dobson Number of articles per category or area of (2009); Lee and Taylor (2013); study; Top countries of study; Top title 


\begin{tabular}{lll}
\hline Group & \multicolumn{1}{c}{ Reference } & \multicolumn{1}{c}{ Variables } \\
\hline & $\begin{array}{l}\text { Muncy and Eastman (1998); } \\
\text { Paschen et al. (2016); Polonsky } \\
\text { and Ringer (2012); Simon et al. } \\
\text { (2014); Van Fleet et al. (2006) }\end{array}$ & $\begin{array}{l}\text { keywords; Article key words and concepts; } \\
\text { The degree of interdisciplinarity }\end{array}$ \\
Methodology & $\begin{array}{ll}\text { Lee and Taylor (2013); Muncy } \\
\text { and Eastman (1998); Paschen } \\
\text { et al. (2016); Simon et al. }\end{array}$ & $\begin{array}{l}\text { Research methodologies (quantitative, } \\
\text { qualitative, mixed method); Research } \\
\text { (2014) }\end{array}$ \\
& $\begin{array}{l}\text { methods used (Experiment, Survey, } \\
\text { Secondary Data, Interview, Other, Multiple } \\
\text { Leethods) }\end{array}$ \\
& & $\begin{array}{l}\text { Editorial board member gender; } \text { Editorial } \\
\text { board member country; } \text { Editorial board } \\
\text { member affiliated institution }\end{array}$ \\
\hline
\end{tabular}

Source: Various as indicated in table

As illustrated in TABLE l, bibliometric studies take on a wide variety of approaches. For the purposes of this study, the main focal points for the bibliometric analysis in this paper will be as summarised in TABLE 2.

\section{TABLE 2: Variables chosen for bibliometric analysis}

\begin{tabular}{lll}
\hline & \multicolumn{1}{c}{ Scope of analysis } & \multicolumn{1}{c}{ Variables } \\
\hline Volume of research & Journal wide & Number of articles per year; \\
Manuscript characteristics & Individual articles & Average page length per article; \\
Article activity & Individual articles & Most downloaded articles; \\
Authorship & Individual articles & Degree of collaboration; Authors per \\
& & article; Top contributing institutions \\
& & (units contributed, papers \\
& contributed); Top contributing \\
& authors (units contributed, papers \\
& contributed); Top author countries; \\
& Author affiliation type (professional, \\
& academic, government, unaffiliated); \\
& Individual articles & $\begin{array}{l}\text { Number of articles per category or } \\
\text { area of study; Top countries of study; }\end{array}$ \\
& Top title keywords; Article key words \\
& and concepts; Degree of \\
& interdisciplinarity
\end{tabular}

Source: Authors' analysis based on TABLE I

The particulars about each subsection of analysis (as summarised in TABLE 2) are discussed individually in the results section that follows. 


\section{RESULTS AND DISCUSSION}

\subsection{Volume of research}

The Journal has had a steady increase in the number of publications per year (see FIGURE 1). Although publication on the 2010 issues were postponed until 2011 due to the protracted accreditation process of the Department of Higher Education and Training, the number of articles published in the Journal increased from an initial 10 per year to 45 per year over the course of the first decade. It should be noted that the number of articles published for 2016 is less because it does not include the articles in the third and final issue of the calendar year.

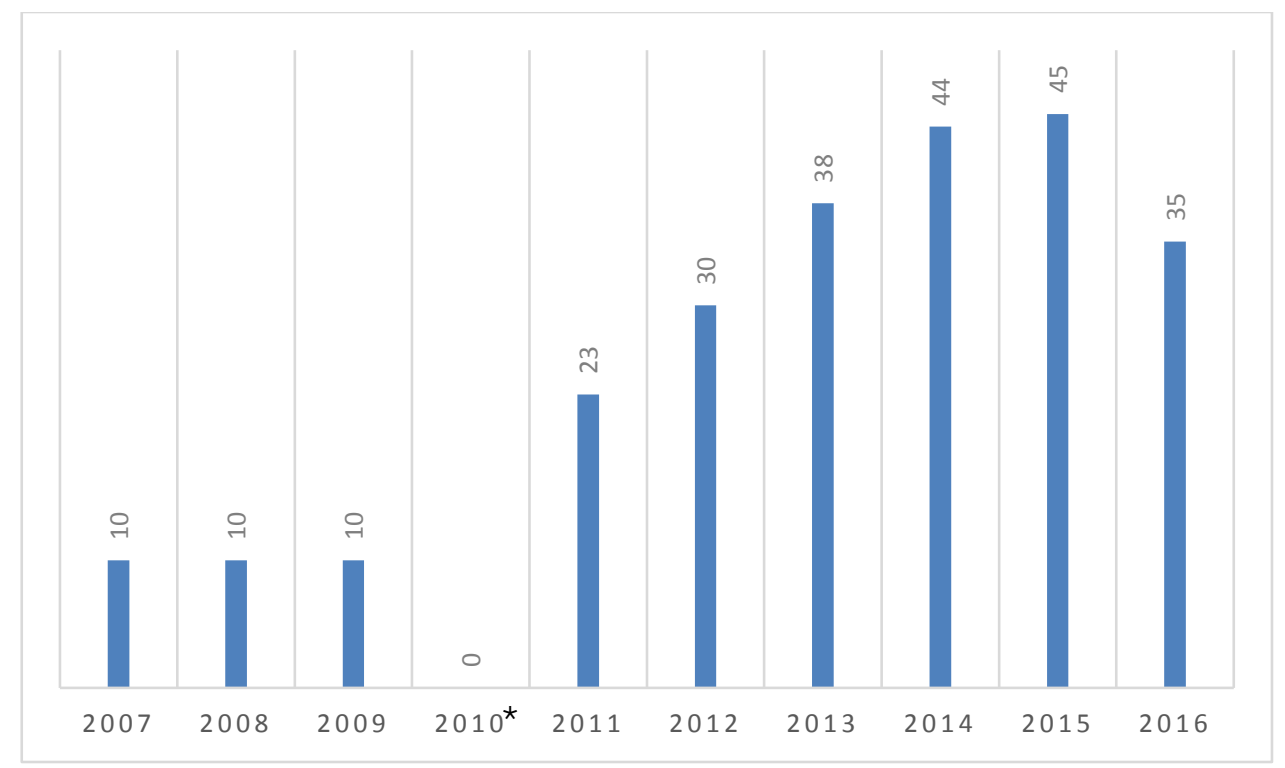

FIGURE 1: Number of articles published per year

Source: Journal of Economic and Financial Sciences

*Note: Publication of the 2010 issues were delayed due to the Department of Higher Education journal accreditation process.

\subsection{Manuscript characteristics}

Between 2007 and 2016, 245 articles have been published in the journal, at an average of 19 pages per article. The longest article was published in 2007 and was 42 pages long with the shortest article published on 6 pages in length. Here it should be noted that the Journal initially published Tax Practice Notes such as the one mentioned above of six pages. The Journal has since changed its Editorial Policy to require an explicit empirical methodology and this has generally resulted in longer papers published in the Journal.

\subsection{Article activity}

Due to lack of available data, the article activity for the entire first decade of the journal cannot be explored. The only data available from Sabinet, the journal's online platform, covers the period 
from October 2015 to September 2016. During this period, 24654 journal articles were downloaded, averaging at approximately 2055 downloads per month.

\subsection{Authorship}

The 245 papers had 461 authors in total, bringing the average number of authors per article to 1,88. The journal appears to be quite collaborative in nature with 166 (or $68 \%$ ) of the articles having more than one author. The number of authors per paper is summarised in TABLE 3 .

TABLE 3: Number of authors per paper

\begin{tabular}{lc}
\hline Number of authors & Number of papers \\
\hline 1 Author & 79 \\
2 Authors & 121 \\
3 Authors & 40 \\
4 Authors & 5 \\
\hline
\end{tabular}

Source: Authors' calculations

The top 10 contributing institutions are summarised in TABLE 4. Here it can be seen that all of the top 10 are South African Universities, spread out across the country. This geographic spread reaffirms the Journal's focus on academic debates from a number of perspectives at a national level, although it should also be stated that the strategy of the Journal in the next decade will also be to expand its non-South African contributors and international footprint.

\section{TABLE 4: The top 10 contributing institutions to the Journal}

\begin{tabular}{|c|c|c|}
\hline Institution & Units & Percentage \\
\hline University of Johannesburg (UJ) & 58.58 & $28.3 \%$ \\
\hline Stellenbosch University (SU) & 46.25 & $22.3 \%$ \\
\hline North-West University (NWU) & 34.17 & $16.5 \%$ \\
\hline University of the Witwatersrand (WITS) & 14.00 & $6.8 \%$ \\
\hline University of South Africa (UNISA) & 12.67 & $6.1 \%$ \\
\hline University of Pretoria (UP) & 11.75 & $5.7 \%$ \\
\hline University of the Free State (UFS) & 9.50 & $4.6 \%$ \\
\hline Nelson Mandela Metropolitan University (NMMU) & 8.17 & $3.9 \%$ \\
\hline University of KwaZulu-Natal (UKZN) & 7.50 & $3.6 \%$ \\
\hline Rhodes University (RU) & 4.75 & $2.3 \%$ \\
\hline TOTAL & \multicolumn{2}{|r|}{207.33} \\
\hline TOTAL ARTICLES & \multicolumn{2}{|r|}{245.00} \\
\hline CONTRIBUTION OF TOP 10 & \multicolumn{2}{|r|}{$84.63 \%$} \\
\hline
\end{tabular}

Source: Authors' calculations 
Interestingly, an effective 207,33 of the total 245 articles were produced by the top 10 contributing institutions, meaning that nearly $85 \%$ of the content published in the Journal were generated by these 10 institutions. This suggests that it is a dense academic community, but it should again be stated that it is the intention of the Journal to expand its depth in terms of contributing institutions.

In light of the successful first decade of the Journal, it is also appropriate to acknowledge the contributions of scholars from a variety of different countries. This is summarised in TABLE 5.

\section{TABLE 5: Top contributing countries}

\begin{tabular}{|c|c|c|}
\hline Country & Country count & Country \% \\
\hline South Africa & 430 & $93 \%$ \\
\hline New Zealand & 4 & $1 \%$ \\
\hline Netherlands & 3 & $1 \%$ \\
\hline Namibia & 3 & $1 \%$ \\
\hline Germany & 3 & $1 \%$ \\
\hline Other* & 18 & $4 \%$ \\
\hline
\end{tabular}

Source: Authors' calculations

*Other includes Finland, Lithuania, USA, England, Zimbabwe, Austria, Ireland, Taiwan, Ghana, Nigeria, France, India and 'Unaffiliated'.

The list of top contributing countries is dominated by authors based at South African universities. The Journal is currently embarking on a journey to expand the international contributions to the Journal. As is expected from a typical academic journal, the authors are also mostly (93\%) from the academia, with only $7 \%$ of authors being either from industry, government or unaffiliated. This is summarised in TABLE 6 .

TABLE 6: Author affiliation type

\begin{tabular}{lcc}
\hline Type & Count & Percentage \\
\hline Academic & 431 & $93.49 \%$ \\
Industry & 19 & $4.12 \%$ \\
Government & 10 & $2.17 \%$ \\
Unaffiliated & 1 & $0.22 \%$ \\
Total & 461 & \\
\hline
\end{tabular}

Source: Authors' calculations

\subsection{Research topics}

In order to uncover the trends in which topics or disciplines the Journal has focused on during its first decade, $\mathrm{NVivo} 10^{\circledR}$ qualitative data analysis software was used to calculate the frequency of 
certain words and related terms in both the title and keywords of each article. In TABLE 7, the word frequencies as they emerge from the article titles clearly indicate the foci of the articles.

\section{TABLE 7: Word frequency in article titles}

\begin{tabular}{|c|c|c|c|}
\hline Word & Count & $\begin{array}{c}\text { Weighted } \\
\text { percentage } \\
(\%)\end{array}$ & Similar words \\
\hline South & 109 & 5.06 & South \\
\hline Africa & 67 & 3.11 & Africa \\
\hline African & 47 & 2.18 & African, Africans \\
\hline Financial & 37 & 1.72 & Financial \\
\hline Tax & 28 & 1.30 & tax, taxes \\
\hline analysis & 22 & 1.02 & Analysis \\
\hline accounting & 20 & 0.93 & $\begin{array}{l}\text { accountancy, accountants, } \\
\text { accountants', accounting }\end{array}$ \\
\hline development & 16 & 0.74 & $\begin{array}{l}\text { developed, developing, development, } \\
\text { developments }\end{array}$ \\
\hline valuing & 16 & 0.74 & value, values, valuing \\
\hline market & 15 & 0.70 & market, markets \\
\hline
\end{tabular}

Source: NVivo10@

The word frequency shown above can also be represented visually, where the size of a word depicts its relative frequency in the entire collection of titles. This is shown in FIGURE 2. 


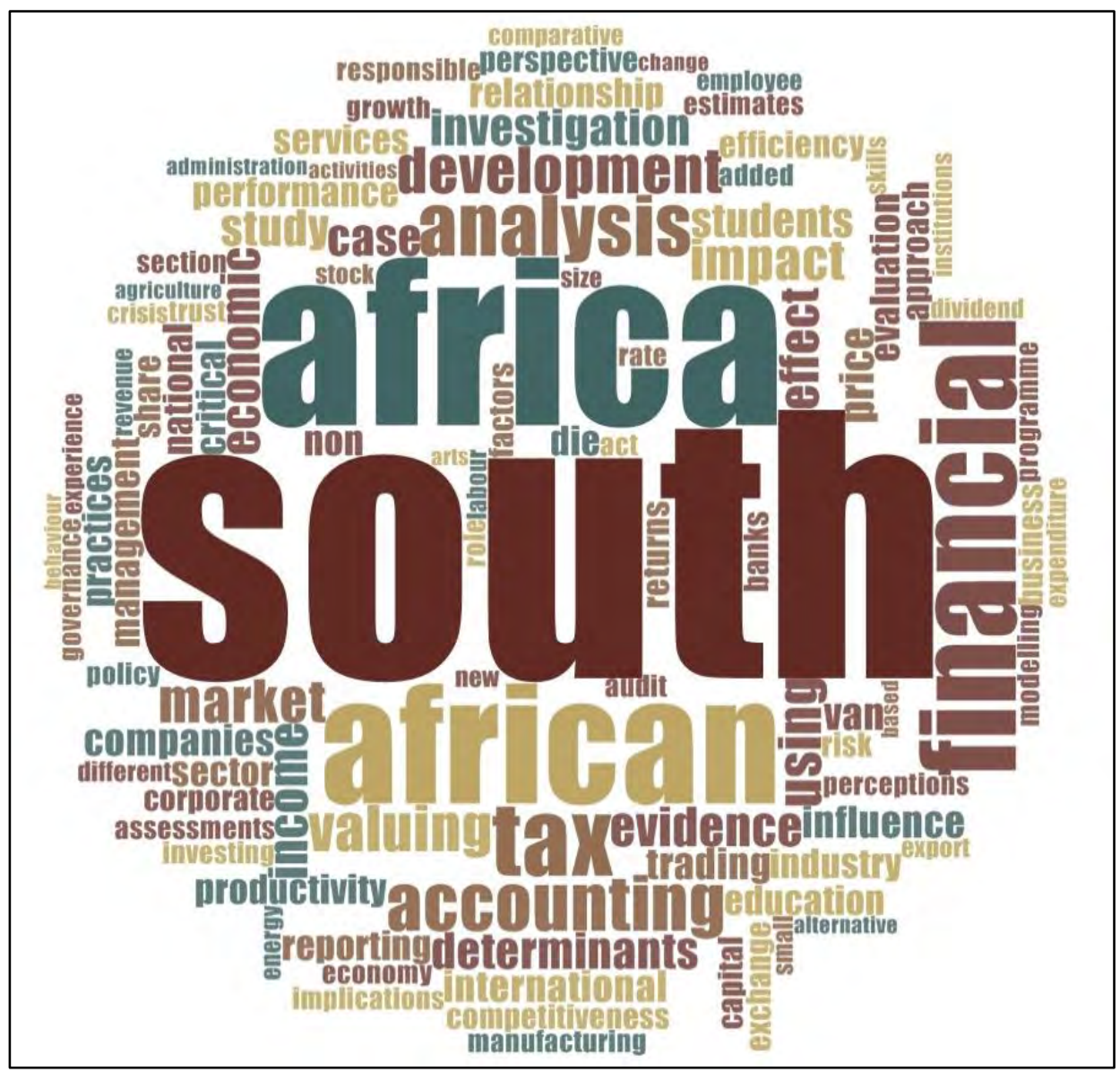

\section{FIGURE 2: Word frequency cloud (Titles)}

Source: NVivolo@

In terms of the keywords for each article, the same frequency analysis was performed. This is summarised in TABLE 8. From both TABLE 7 and TABLE 8, it is clear that the Journal focused heavily on South African matters, which is dominated by contributions that focused on 'financial', 'tax', 'accounting', 'economic' and 'management' issues. 
TABLE 8: Word frequency in article keywords

\begin{tabular}{|c|c|c|c|}
\hline Word & Count & $\begin{array}{c}\text { Weighted } \\
\text { percentage } \\
\text { (\%) }\end{array}$ & Similar words \\
\hline financial & 62 & 2.05 & Financial \\
\hline south & 46 & 1.52 & South \\
\hline $\operatorname{tax}$ & 46 & 1.52 & tax, taxes \\
\hline accounting & 43 & 1.42 & $\begin{array}{l}\text { account, accountancy, accountant, } \\
\text { accountants, accounting }\end{array}$ \\
\hline africa & 40 & 1.32 & Africa \\
\hline economic & 31 & 1.02 & economic, economics \\
\hline developments & 30 & 0.99 & $\begin{array}{l}\text { developed, developing, development, } \\
\text { developments }\end{array}$ \\
\hline market & 30 & 0.99 & market, marketing, markets \\
\hline management & 28 & 0.92 & management, manager \\
\hline risk & 26 & 0.86 & risk, risks \\
\hline
\end{tabular}

Source: NVivo10®

Again, the word frequency is represented visually, as shown in FIGURE 3. 


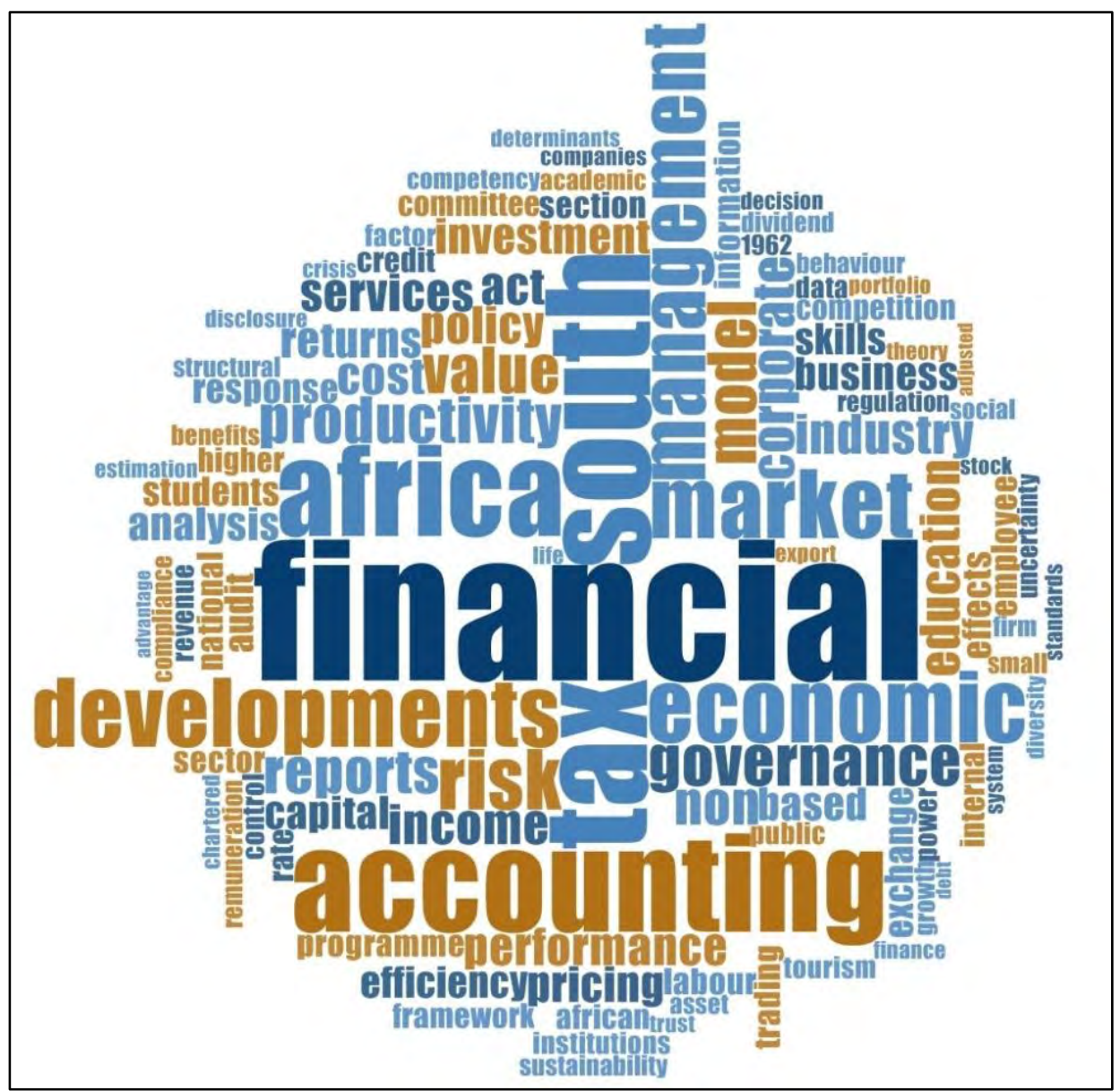

\section{FIGURE 3: Word frequency cloud (Keywords)}

Source: NVivo10®

These word frequencies within the keywords presented above were used for further analysis of clusters in the focus of the journal. Using NVivo $10^{\circledR}$, the prevalence of certain topic clusters can be identified using Word Tree Diagrams. These diagrams for 'accounting', 'economic', 'financial', 'management' and 'tax' are shown in FIGURES 4 to 8. 


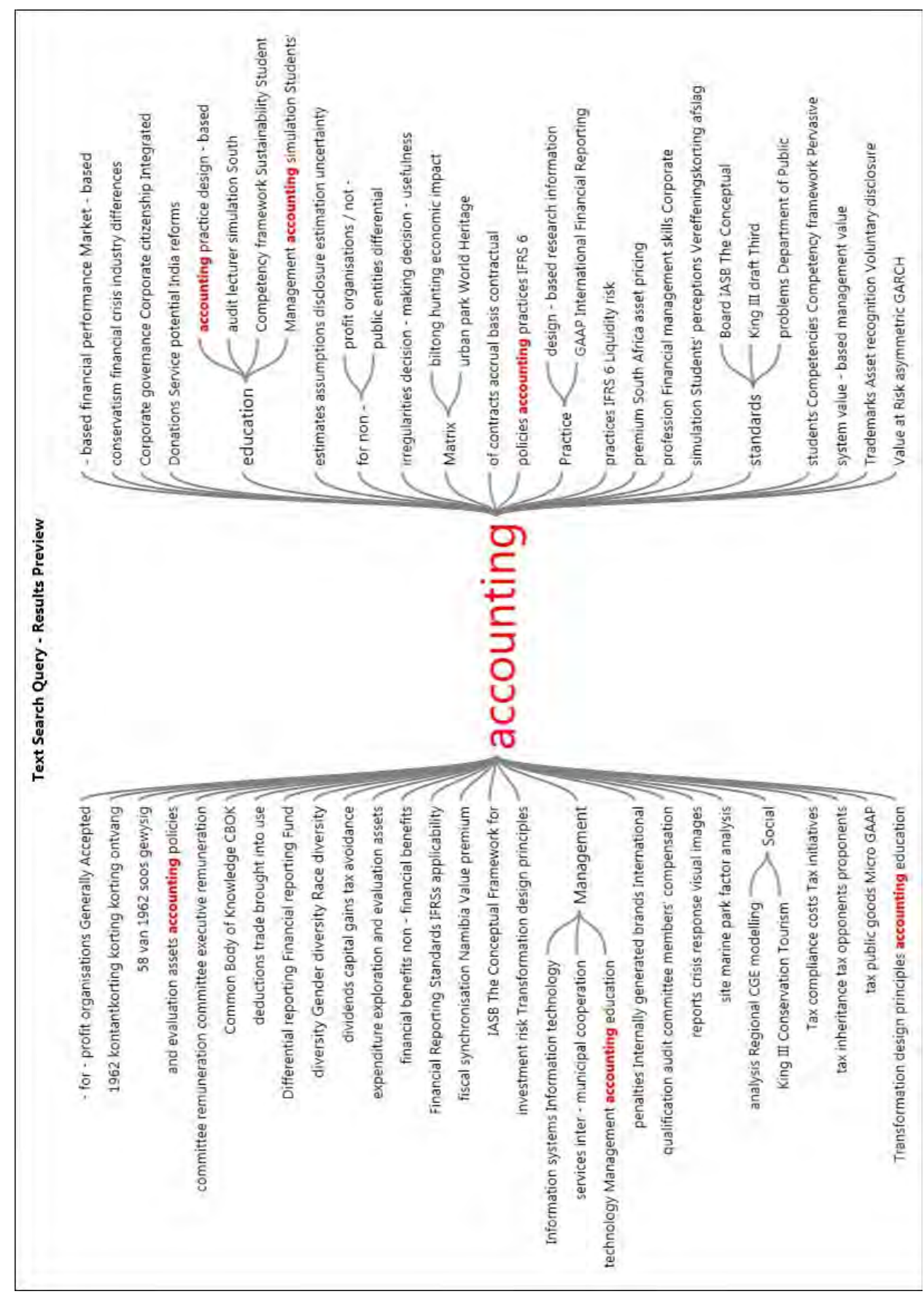

FIGURE 4: Word Tree Diagram: 'Accounting'

Source: NVivol0巴 


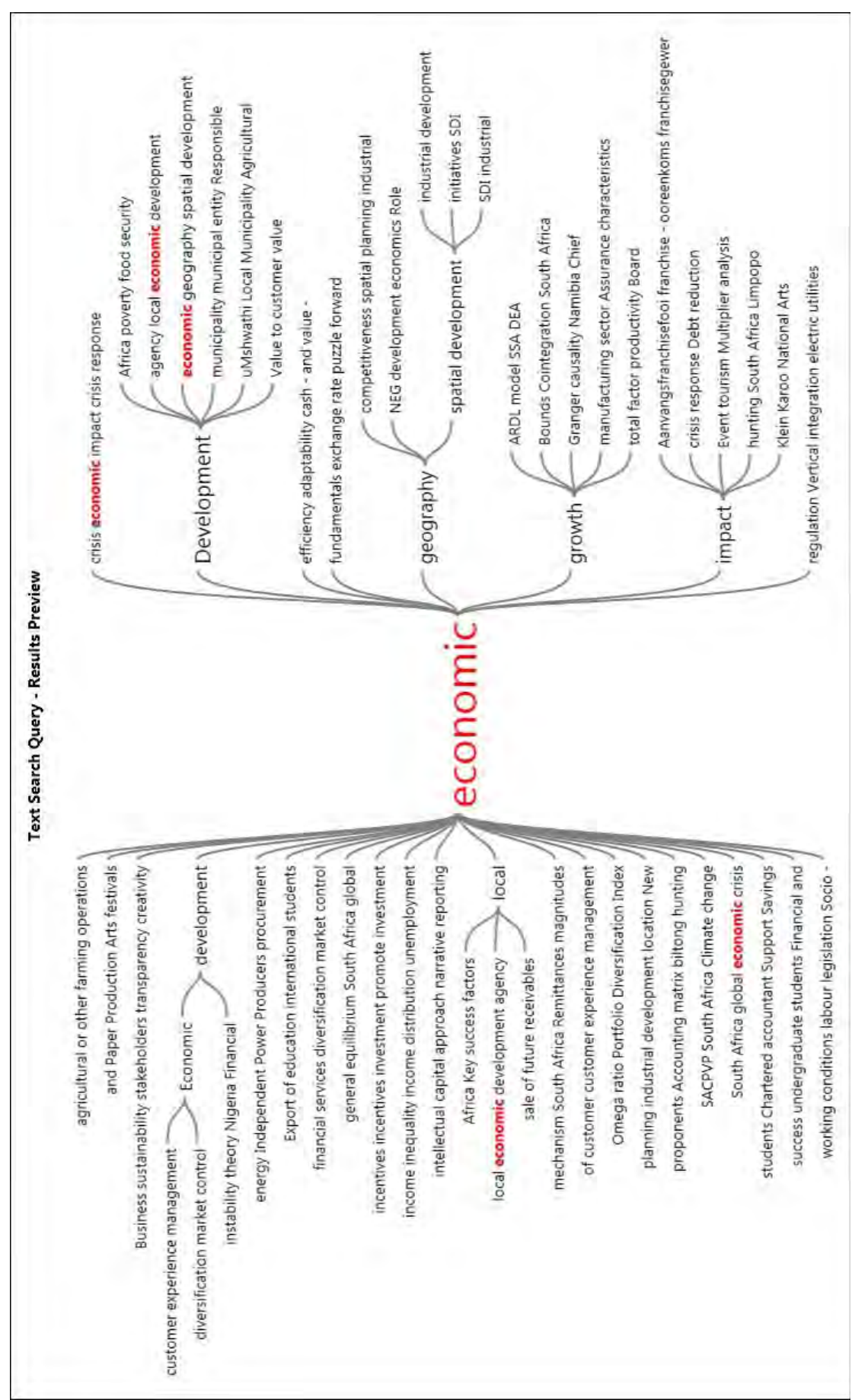

FIGURE 5: Word Tree Diagram: 'Economic'

Source: NVivo10® 


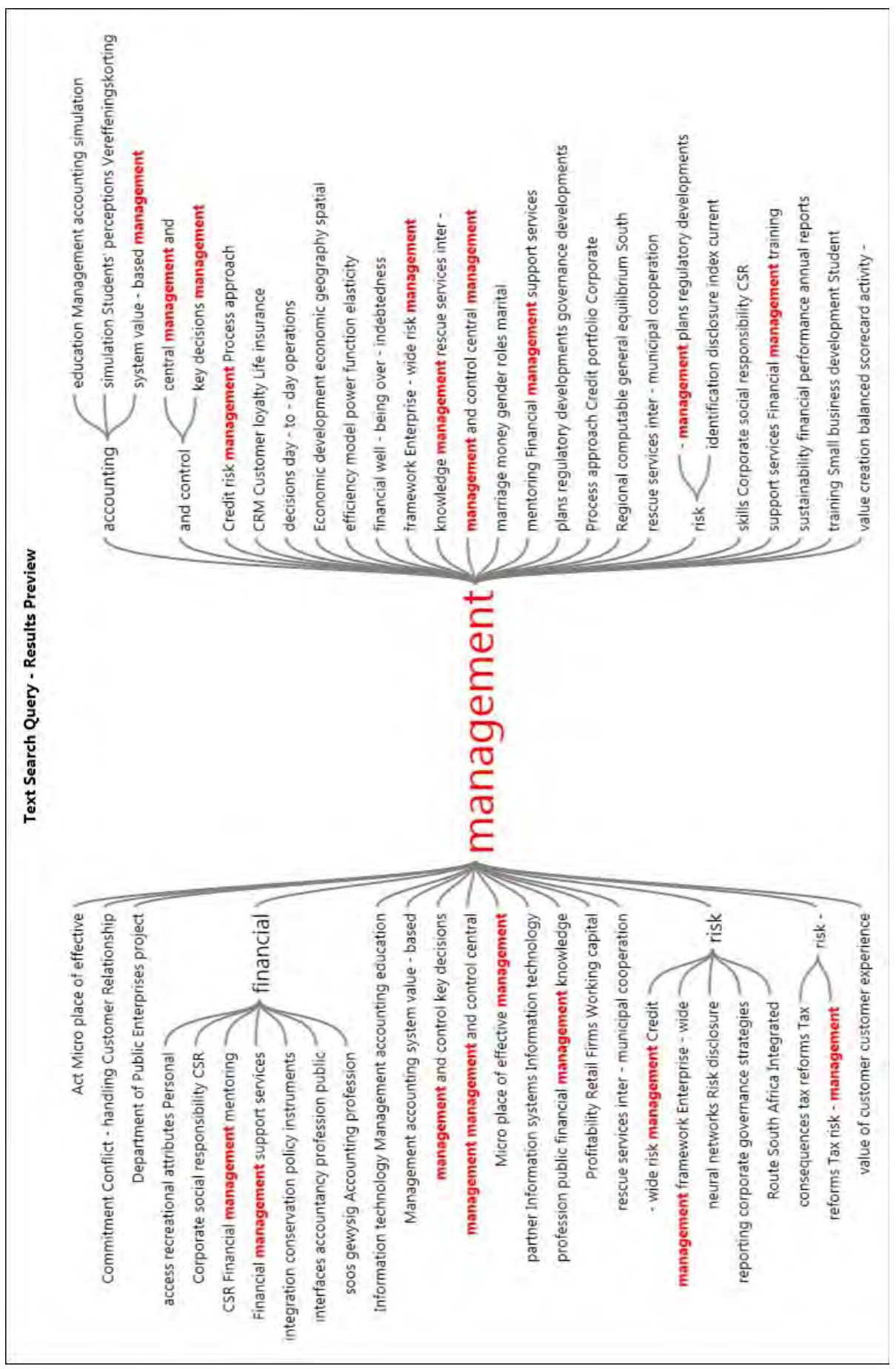

FIGURE 6: Word Tree Diagram: 'Management'

Source: NVivo10巴 


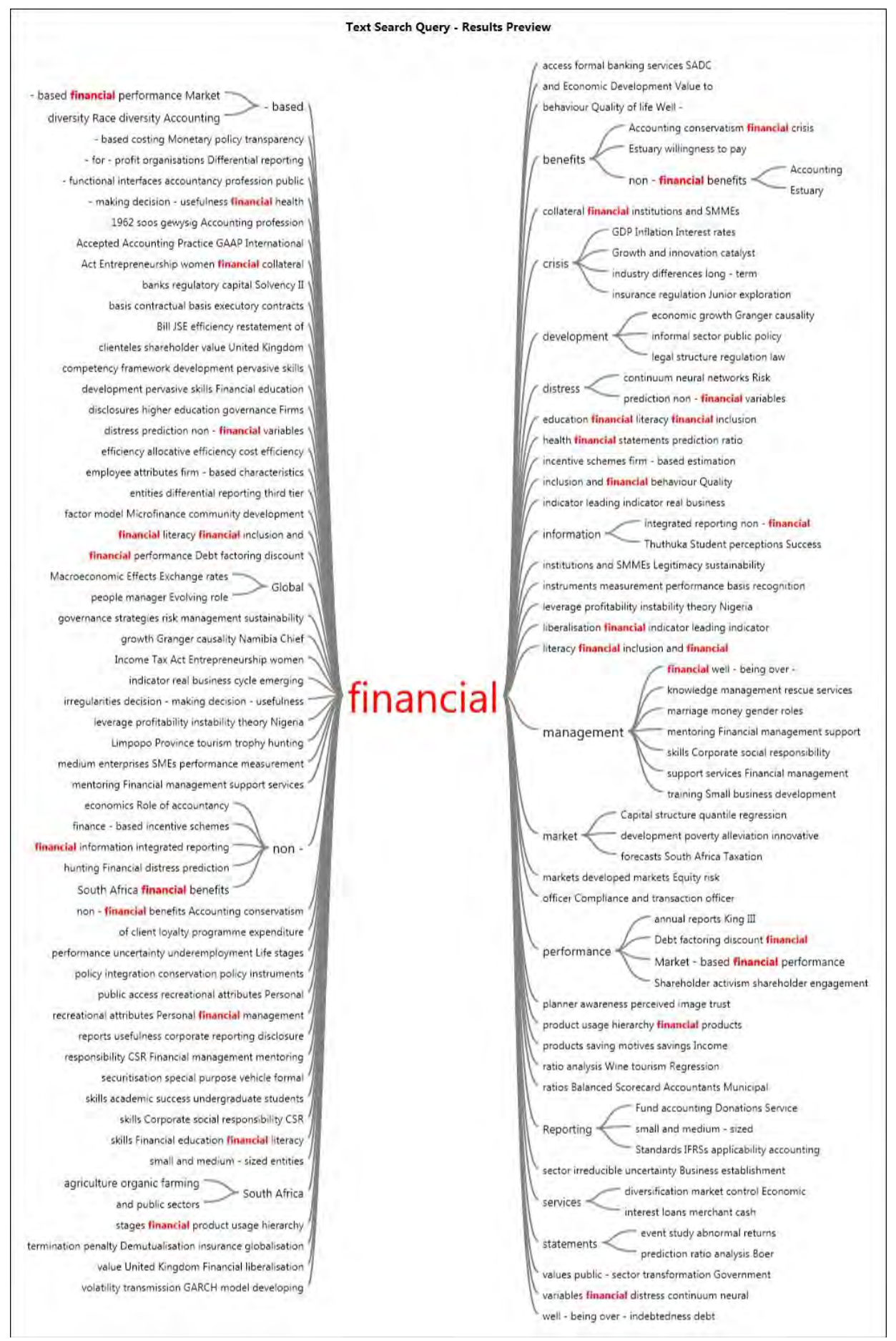

FIGURE 7: Word Tree Diagram: 'Financial'

Source: NVivo10 ${ }^{\circledR}$ 


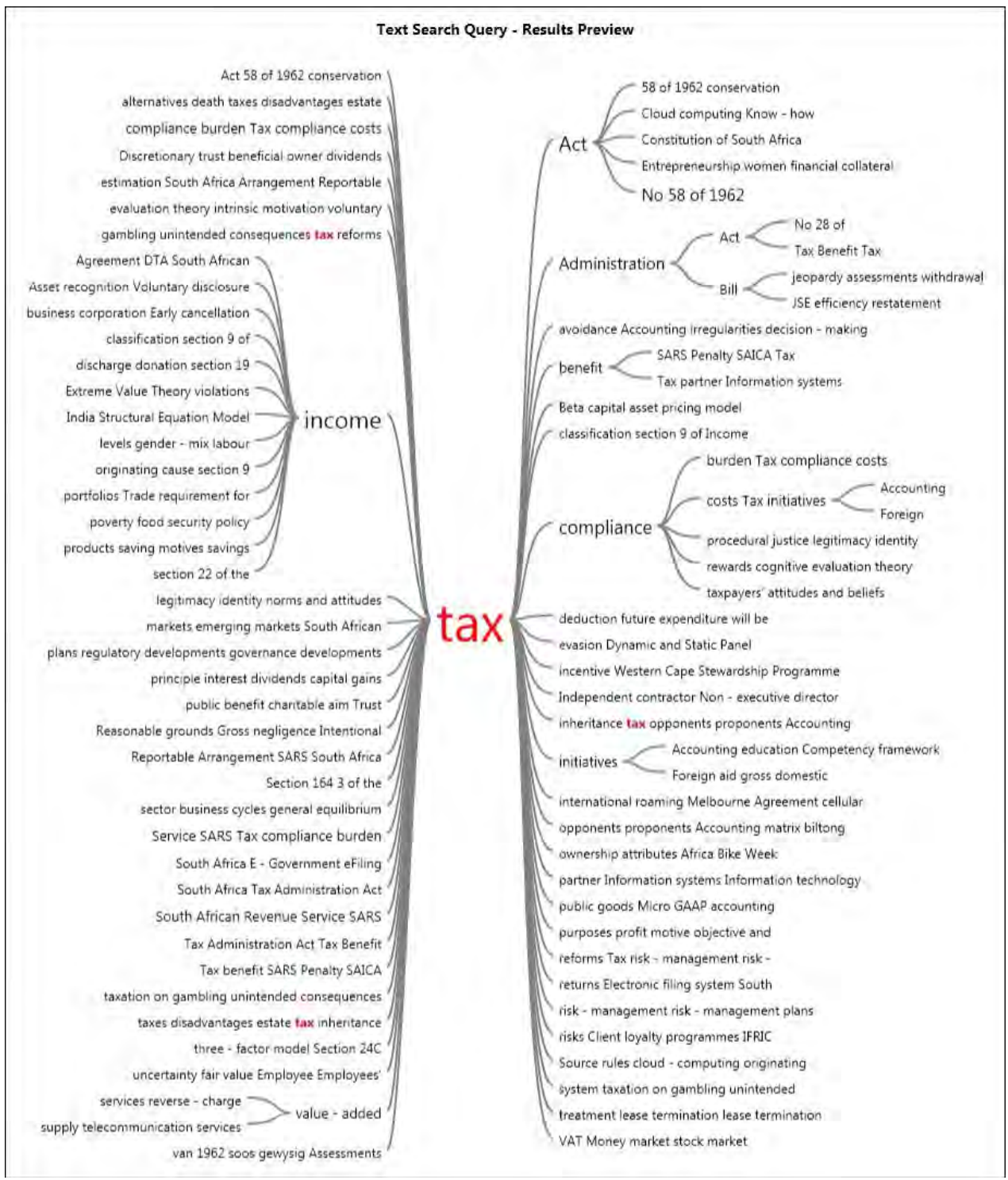

\section{FIGURE 8: Word Tree Diagram: 'Tax'}

Source: $\quad$ NVivolo®

From the Word Tree Diagrams the clusters (or sub-disciplines) emerge for each major focus area of the Journal. For 'Accounting' it is clear that the major clusters are Management Accounting, Social Accounting, Accounting Education, Accounting Practice and Accounting Standards (FIGURE 4). For 'Economic', the major clusters are Local Economics, Economic Development, Economic Geography, Economic Growth and Economic Impact of various matters (FIGURE 5). For 'Management', the main clusters are Financial Management, Risk Management, Financial Accounting, as well as Management and Control (FIGURE 6). The ambiguity of the term 'Management' results in a relatively fragmented diagram, but due to the interdisciplinarity of the Journal, the major topics still emerge from the diagram. For the term 'Financial' the main clusters 
are Global Financial, Non-Financial, Financial Benefits, Financial Crisis, Financial Development, Financial Distress, Financial Information, Financial Management, Financial Markets, Financial Performance, Financial Reporting, Financial Services and Financial Statements (FIGURE 7). Once again, the fact that the term 'financial' is a regularly used term in the related but independent fields of Accounting, Financial Management, Investment Management, Financial Planning and Economics means that a variety of disciplines are represented here in the diagram. Finally, for the term 'Tax', the main clusters are Income Tax, Tax Act, Tax Administration, Tax Benefits, Tax Compliance, and Tax Initiatives.

In order to facilitate a deeper analysis of the trends within the topics covered by the journal, a content analysis was also performed on the entire collection of articles published in the journal.

\subsection{Content analysis of topics}

Content analysis can be defined as "a systematic, replicable technique for compressing many words of text into fewer content categories based on explicit rules of coding" (Stemler, 2001:1). The aim of this content analysis was to categorise each paper into a certain overarching, mutually exclusive and exhaustive topic categories (Stemler, 2001) in order to facilitate the calculation of descriptive statistics. In order to facilitate the content analysis, a priori coding procedures were established. Weber (1990) defines a priori coding as a coding procedure whereby categories are established before the analysis based on theory or agreement between professional colleagues. The 'theory' in this case is replaced by the key disciplines within the journal scope: auditing, corporate finance, corporate governance, economics, econometrics, financial accounting, financial management, financial planning, investment management, management accounting and taxation. To ensure an exhaustive set of categories, a final category 'Other' was added to the list. All items that do not fall into one of the abovementioned categories are classified as 'Other' and analysed in a second round of content analysis.

To ensure the validity and reliability of the content analysis, two coders performed the coding independently, and the inter-coder reliability is examined by calculating the percentage agreement between coders (Stemler, 2001) as well as Cohen's Kappa (Cohen, 1960; Stemler, 2001; Simon et al., 2014).

Cohen's Kappa can be calculated as follows (Stemler, 2001):

$$
\varkappa=\frac{P_{A}-P_{C}}{1-P_{C}}
$$

where:

$P_{A}=$ proportion of units on which the coders agree

$P_{C}=$ proportion of units for which agreement is expected by chance.

In order to interpret Cohen's Kappa, Landis and Koch (1977:165) have suggested the categories as shown in TABLE 9. 
TABLE 9: Interpretation of Cohen's Kappa

\begin{tabular}{cc}
\hline Kappa value & Strength of Agreement \\
\hline 0.00 & Poor \\
$0.00-0.20$ & Slight \\
$0.21-0.40$ & Fair \\
$0.41-0.60$ & Moderate \\
$0.61-0.80$ & Substantial \\
$0.81-1.00$ & Almost Perfect \\
\hline
\end{tabular}

Source: Landis and Koch (1977:165)

From the first round of coding by the two independent coders, the percentage agreement between coders was calculated at $80 \%$ and Cohen's Kappa was found to be 0.761 , indicating a substantial strength of agreement between the two independent coders. The difference between the percentage of agreement and Cohen's Kappa indicates the level of agreement that can be ascribed to pure chance (Stemler, 2001; Cohen, 1960), in this case indicating that the agreement due to chance is only approximately $4 \%$. This demonstrates the inter-coder reliability of the coding procedure to accurately classify the 245 papers published in the JEF during the first decade into certain predetermined topic categories. The wide variety of topics covered by the journal scope, as well as the relative ambiguity of the discipline into which certain papers fall (e.g. the tax implications of certain dividend policies, which may be classified as either 'taxation' of 'finance') make a higher Kappa value improbable.

After measuring the inter-coder reliability, the content analysis was revised in order to arrive at a final set of topic categories for the body of literature in the journal. The revision was based on two procedures:

1. Instances of disagreement between coders were revisited and, with further investigation of the paper content, reclassified into a single topic category agreed upon by both coders.

2. Instances where both coders categorised a paper as 'Other' were subject to further investigation in order to form sub-classifications for these papers.

After these corrections, the following results were obtained. Out of the 245 papers published in the journal, 205 (or $84 \%$ of papers) fell into the main categories as listed in the journal scope.

TABLE 10 demonstrates the concentration of the papers published in the journal during its first decade of existence. The largest focus areas of the journal in terms of topics were economics $(28 \%)$, Taxation (18\%) and Finance (12\%). The high concentration of papers in particular disciplines suggests that there might be scope for launching more focussed journals (i.e. a journal for research on the South African tax environment) in the future.

In terms of the papers classified as 'Other', TABLE 11 summarises the sub-classifications made during a second round of content analysis on these papers. For this round of content analysis, an emergent coding procedure was used. For an emergent coding procedure, "categories are established following some preliminary examination of the data" (Stemler, 2001:3). 
TABLE 10:Content analysis of topic categories in JعF

\begin{tabular}{lcc}
\hline Topic category & Number of papers & Percentage of papers \\
\hline Accounting & 20 & $8 \%$ \\
Auditing & 6 & $2 \%$ \\
Corporate Governance & 10 & $4 \%$ \\
Economics & 69 & $28 \%$ \\
Financial Planning & 12 & $5 \%$ \\
Finance & 29 & $12 \%$ \\
Investment Management & 12 & $5 \%$ \\
Management Accounting & 4 & $2 \%$ \\
Taxation & 43 & $18 \%$ \\
\hline Other* & 40 & $16 \%$ \\
\hline TOTAL & 245 & $100 \%$ \\
\hline
\end{tabular}

Source: Authors' calculations

* Other includes papers from a variety of disciplines that do not fall into the abovementioned categories. These papers are analysed separately below.

TABLE 10 demonstrates the concentration of the papers published in the journal during its first decade of existence. The largest focus areas of the journal in terms of topics were economics $(28 \%)$, Taxation (18\%) and Finance (12\%). The high concentration of papers in particular disciplines suggests that there might be scope for launching more focussed journals (i.e. a journal for research on the South African tax environment) in the future.

In terms of the papers classified as 'Other', TABLE 11 summarises the sub-classifications made during a second round of content analysis on these papers. For this round of content analysis, an emergent coding procedure was used. For an emergent coding procedure, "categories are established following some preliminary examination of the data" (Stemler, 2001:3).

TABLE 11 explores the topics of the papers that do not fall into the main themes of the journal. These papers focussed mostly on Education (often on the education of finance or accounting students) (30\%), economic sociology (25\%) and tourism studies (20\%). While these studies do not fall directly into the main themes of the journal, they do contribute valuable insight into the economic and financial environment of South Africa and other countries.

\section{CONCLUSION}

The JEF has gone from strength to strength in its first decade, and the developments detailed in this paper provides a good foundation for the journal's continued service to the academic community in the decades to come. The journal enjoys a wide readership, with nearly 25000 downloads during the last year (or an average of 68 downloads per day). The majority of papers were written by two or more authors, with only $32 \%$ of papers being written by a sole author. The 
contributing institutions are spread across South Africa, and the journal aims to attract a larger contribution from international institutions.

TABLE 11:Sub-categorisation of papers classified as 'Other'

\begin{tabular}{lcc}
\hline Topic category & Number of papers & Percentage of papers \\
\hline Education & 12 & $30 \%$ \\
Economic Sociology & 10 & $25 \%$ \\
Ethics & 2 & $5 \%$ \\
Logistics/Transport Economics & 2 & $5 \%$ \\
Management/Organisational Research & 5 & $13 \%$ \\
Real estate & 1 & $3 \%$ \\
Tourism studies & 8 & $20 \%$ \\
TOTAL & 40 & $100 \%$ \\
\hline
\end{tabular}

Source: Authors' calculations

As expected, the journal focussed mainly on matters of Economics (more specifically development economics, economic geography, economic growth and economic impact of certain events), Taxation (more specifically income tax matters, research on various Tax Acts, and tax compliance) and Finance (more specifically, research on financial crises, financial development, financial distress, financial performance, financial markets, and financial reporting/statements), while also making contributions to the fields of education, economic sociology, tourism studies and others.

In the next decade the Journal will seek to actively increase its footprint both from a readership and authorship perspective. Much work has gone into this strategy thus far with the change of the administration of the Journal from a manual approach to that of an online approach. From 2015 all Journal administration has been dealt with using the $\mathrm{ScholarOne}^{\circledR}$ online application. This has also had the added benefit that journal metrics and statistics can now be tracked and calculated with much more ease.

Discussions are also happening to look at the possibility of moving the Journal into an Open Source community. Although all historic issues of the Journal appears for free to researchers and readers on the Sabinet Network, the use of applicable Open Source software will also mean that the Journal can be administered at a much lower cost. It will also have the added benefit that the Journal can then appear in the Directory of Open Source Journals (DOAJ) which will enhance the Journal citations on the various academic indices worldwide. For authors it will mean that their work is then much easier to be recognised and cited by other researchers. Important authors' metrics such as impact factors (i.e. the frequency with which the average article in a journal has been cited in a particular year) and inclusion in the international journal ranking will then also be possible. 


\section{LIST OF REFERENCES}

Armstrong, S. \& Wilkinson, A. (2007). Processes, procedures and journal development: Past, present and future. International Journal of Management Reviews, 9(2), pp. 81-93. doi: 10.1111/j.14682370.2007.00207.x.

Cohen, J. (1960). A coefficient of agreement for nominal scales. Educational and Psychological Measurement, 20, pp. 37-46.

Dabirian, A., Diba, H., Tareh, F. \& Treen, E. (2016). A 23-Year Bibliometric Study of the Journal of Food Products Marketing. Journal of Food Products Marketing. doi: 10.1080/10454446.2016.1141141.

Dobson, I.R. (2009). The Journal of Higher Education Policy and Management: an output analysis. Journal of Higher Education Policy and Management, 31(1), pp. 3-15. doi: 10.1080/13600800802558833.

Els, G. (2007). Editorial: April 2007. Journal of Economic and Financial Sciences, 1(1), p. 5. Hertzel, D.H. (1987). History of the development of ideas in bibliometrics. In A. Kent (દd.), Encyclopedia of library and information science, 42, pp. 144-219. New York: Marcel Dekker.

Hood, W. \& Wilson, C., 2001. The literature of bibliometrics, scientometrics, and informetrics. Scientometrics, 52(2), pp.291-314. Information Science and Technology, Vol. 24, Elsevier Science Publishers B.V. for the American

Journal of Economic and Financial Sciences. (2015). Editorial Policy. Journal of Economic and Financial Sciences, 8(3), pp. 890-896.

Landis, J.R. \& Koch, G.G. (1977). The measurement of observer agreement for categorical data. Biometrics, 33, pp. 159- 174.

Lee, C.A. \& Taylor, M.J. (2013). Moral education trends over 40 years: A content analysis of the Journal of Moral Education (1971-2011). Journal of Moral Education, 42(4), pp. 399-429. doi: $10.1080 / 03057240.2013 .832666$.

Merigó, J.M., Mas-Tur, A., Roig-Tierno, N. \& Ribeiro-Soriano, D. (2015). A bibliometric overview of the Journal of Business Research between 1973 and 2014. Journal of Business Research, 68, pp. 26452653. doi: 10.1016/j.jbusres.2015.04.006.

Muncy, J.A. \& Eastman, J.K. (1998). The Journal of Advertising: Twenty-Five Years and beyond. Journa/ of Advertising, 27(4), pp. 1-8. doi: 10.1080/00913367.1998.10673565.

Okubo, Y. (1997). Bibliometric indicators and analysis of research systems: Methods and examples. STI Working Papers, 1997/1, 0ECD Science.

Paschen, J., Wilson, M., Nehajowich, J. \& Prpic, J. (2016) Fine wine through time: a review of the Journal of Wine Research. Journal of Wine Research, 27(2), pp. 91-104. doi: 10.1080/09571264.2016.1173534.

Polonsky, M.J. \& Ringer, A. (2012). Twenty Years of the Journal of Marketing Theory and Practice. Journal of Marketing Theory and Practice, 20(3), pp. 243-262. doi: 10.2753/MTP1069-6679200301.

Pritchard, A. (1969). Statistical Bibliography or Bibliometrics. Journal of Documentation, 25(4) pp. 348-349.

Quevedo-Blasco, R. \& Ariza, T. (2013). Twenty-five year history of the journal Psicothema. Psicothema, 25(1), pp. 93-99.

Broadus, R.N. (1987). Towards a definition of bibliometric. Scientometrics, 12(5/6), pp. 373-379. 
Ramos-Rodríguez, A. R. \& Ruiz-Navarro, J. (2004). Changes in the intellectual structure of strategic management research: A bibliometric study of the strategic management journal, 1980-2000.

Strategic Management Journal, 25, pp. 981-1004. doi:10.1002/smj.397

Shapiro, F. R. (1992). Origins of bibliometrics, citation indexing, and citation analysis: The neglected legal literature. Journal of the American Society for Information Science (1986-1998), 43(5), p. 337.

Simon, C.B., Coronado, R.A., Wurtzel, W.A., Riddle, D.L. \& George, S.Z. (2014). Content and bibliometric analyses of the Journal of Manual \& Manipulative Therapy. Journal of Manual \& Manipulative Therapy, 22(4), pp. 181-190. doi: 10.1179/2042618614y.0000000075.

Stemler, S. (2001). An overview of content analysis. Practical Assessment, Research \& Evaluation, 7(17). Available: http://PAREonline.net/getvn.asp?v=7\&n=17. (Accessed 2 December 2014).

Van Fleet, D.D., Ray, D.F., Bedeian, A.G., Downey, H.K., Hunt, J.G., Griffin, R.W., Dalton, D., Vecchio, R.P., Kacmar, K.M. \& Feldman, D.C. (2006). The Journal of Management's First 30 Years. Journal of Management, 32, pp. 477-506. doi: 10.1177/0149206306286715.

Weber, R.P. (1990). Basic Content Analysis, $2^{\text {nd }}$ edition. California: Newbury Park.

White, H.D. \& McCain, K.W. (1989). Bibliometrics. In: M.E. Williams (Ed.), Annual Review of Information Science and Technology, 24, pp. 119-186. Amsterdam: Elsevier. 